\begin{tabular}{|l|l|l||}
\hline \multicolumn{2}{|c|}{ PublisherInfo } \\
\hline \hline PublisherName & $:$ & BioMed Central \\
\hline \hline PublisherLocation & $:$ & London \\
\hline \hline PublisherImprintName & $:$ & BioMed Central \\
\hline \hline
\end{tabular}

\title{
SMaRT correction
}

\begin{tabular}{|l|l|l||}
\hline \multicolumn{2}{|c|}{ ArticleInfo } \\
\hline \hline ArticleID & $:$ & 4372 \\
\hline \hline ArticleDOI & $:$ & $10.1186 /$ gb-spotlight-20020109-01 \\
\hline \hline ArticleCitationID & $:$ & spotlight-20020109-01 \\
\hline \hline ArticleSequenceNumber & $:$ & 38 \\
\hline \hline ArticleCategory & $:$ & Research news \\
\hline ArticleFirstPage & $:$ & 1 \\
\hline \hline ArticleLastPage & $:$ & 2 \\
\hline \hline & $:$ & RegistrationDate : 2002-01-09 \\
ArticleHistory & $:$ & OnlineDate \\
\hline \hline ArticleCopyright & $:$ & BioMed Central Ltd2002-01-09 \\
\hline \hline ArticleGrants & $:$ & \\
\hline \hline ArticleContext & $:$ & 130593311 \\
\hline \hline
\end{tabular}




\section{Jonathan B Weitzman}

Email: jonathanweitzman@hotmail.com

A technique called SMaRT (spliceosome-mediated RNA Trans-splicing) has been developed to generate functionally corrected mRNA transcripts and proteins in patients with genetic diseases. In the January issue of Nature Biotechnology, Liu et al. describe the use of SMaRT technology to correct endogenous $\triangle \mathrm{F} 508$ mutations in the cystic fibrosis transmembrane conductance regulator $(C F T R)$ gene (Nature Biotechnology 2002, 20:47-52). They constructed recombinant adenoviral vectors containing CFTR exons 10-24 and a trans-splicing domain. These could partially restore CFTR chloride ion conductance in $\triangle \mathrm{F} 508$ airway epithelial cells in vitro. The SMaRT vectors resulted in the expression of corrected CFTR mRNA and protein. Liu et al. also demonstrated functional correction in vivo using a human bronchial xenograft model. These results show the potential feasibility of using SMaRT technology to correct, rather than replace, defective genes.

\section{References}

1. Spliceosome-mediated RNA trans-splicing as a tool for gene therapy.

2. Nature Biotechnology, [http://biotech.nature.com] 